\title{
Utilization of Fashion Practice Waste to Increase Students' Creativity
}

\author{
Hapsari Kusumawardani, Nurul Aini, Ma'rifatun Nashikhah \\ Department of Industrial Technology \\ Universitas Negeri Malang \\ Malang, Indonesia \\ hapsari.kusumawardani.ft@um.ac.id
}

\begin{abstract}
Waste is unused material which couldbe recycled to be something more useful. Study Program of Fashion Design Education is one of the fabric waste and textile dye waste producer. The students' creativity is required to utilize those kind of wastes become something that has economy value. For examples, the fabric waste couldbe recycled as a complement on kids fashion while the textile dye waste couldbe recycled to color dry seeds, flowers, or rinds which use as accessories
\end{abstract}

Keywords - Waste; students' creativity

\section{INTRODUCTION}

Waste is unused thing which needs to recycle if it is not recycled it will bring many negative effects that couldaffect human's health and the nature ecosystem. Waste couldbe found in many places such as school, household, industry, offices, hospital and etc. Not only such places, some events and reception also produce the waste like leftovers, plastic bottle and glasses, paper plates, tissue and etc. We also easily find the waste in the road. However, the industries also bring the waste. Based on information given from Ministry of Environment, every single day one person at least produces 0.8 wastes. By calculating the number of Indonesian residents, the waste achieves 176.000 tons per day [1]. If those numbers of the wastes are not well-manage, how bad the effects are to the human's life and environment?

Those wastes also contribute to the global warming even though the industry revolution is assumed as the main cause. As the global warming effects already affected environment, people nowadays start to find out the way how to avoid and minimalize the effects. Unravel waste of textile waste is the kind of waste that produce by fashion industry that also contribute of global warming [2]. Most of the residents manage their waste by their own ways by burning, littering, or wasting it to the river. It is clearly caused another pollution problems water, land, and air pollutions.Recently, some conscious residents of Yogyakarta has utilized the plastic waste becomes an energy alternative to replace solar as the fuel of diesel.

\section{A. Waste}

Waste issues should become our awareness as the residents of the world to minimalize it. One of the wastes contributors of fabric waste is university, especially Department of Industry Technology, majoring in Fashion Design because after the practice lesson the students produce a lot of fabric waste such as patchwork, yarn waste, paper waste, textile color, and etc.

According to Government Regulation Number 101 year 2014, waste is residue of a business or activities. Based on Hafiuddin (2012), waste forms are grouped into:

- Solid waste, this kind of wastes are solid, dry, could not move by itself such as paper pieces, fabric waste, wood pieces, leftovers.

- Liquid waste, this kind of waste are such a liquid, it never stops and always moves such as textile dye waste and dishes water.

- Gas waste, this kind of wastes is a gas waste which could be seen in form of smoke. Gas waste is always moving so it widely spreads

Then, according to another sources, kinds of wastes are categorized into: a) Domestic Waste (Household waste), b) Industry Waste, c) Agriculture waste, d) Mining Waste, e) Tourism waste, f) Medical waste.

\section{B. Waste of Fashion Design Practice}

Fabric waste producers are not only come from textile industry, but it also comes from universities or schools with Fashion Design as one of their major. This major has activities that allow the students to make clothes pattern, produce the clothes, fabric dyeing practice, practice to make linen, embroidery, and other practices that in every process also produces waste. Every student from every class who practice fashion design production always produces fabric waste that wasted unused. Furthermore, some of those fabric wastes are in good large pieces that could be used as variant of the product which has economy value.

[3] mentioned that by processing those fabric wastes in a well and appropriate ways, those fabric wastes have potential to be a high-valued product. Susilo and Karya had observed that fabric waste which is mixed with resin, putty, cement, sago flavor, and gumrosin change the fabric's structure to produce new products such as furniture. In Bachelor Art and Design of ITB Journal, Wicaksono also utilized the fabric waste to produce ghillie suit, this kind of suit is worn by military to camouflage resembles the bush. He used lighten fabric waste such as cotton and linen which well-known as flexible material and does not absorb the heat that suitable for military. 


\section{METHOD}

This paper uses a conseptual method that refers to same related references. this conceptual method presents writings on the definition of waste, waste classification and potential waste that can be reprocessed and utilized into products that have a sale value.

\section{RESULT AND DISCUTION}

University students are bachelor candidate that officially registered to study in university. As a generation that is expected to be intellectual, those students have to know how to develop themselves by doing positive and creative activities, especially for students of Fashion Design. Students of this department are surely taught to have useful soft and hard skills that couldbe used to enter national programs in order to hone their intellectuality and skills.

Directorate of Research and Community Service makes programs to develop creativity of university students so they could have academic and professional skills in the society. A variety of Students' Creativity Programs which are held by the Directorate of Research and Community Service are the opportunity for the students to be more concerned of minimalize practice waste by utilizing it to produce new products that has economy value. The fabric waste or patchwork could be categorized based on its size. The fabric that is large is used as accessories or complement material of other things such as clothes, while the smaller fabric waste could be used as filler material.

The following is an example of the use of patchwork as a complement to children's clothing, with the steps to make it as follows:

1) Choosing a patch according to the type of fabric

2) used as the base of clothing

Cutting the pattern according to the pattern and size

Setting a piece of rag on a sheet of coating material

3) (viselin) tightly

Iron every piece of the patch until the patch is flat

Each border of the rectangle is resolved by zigzaging

4) it as a brace and ornament

Decorative pieces of cloth cut in the form of fashion

5) patterns

Tailoring and connecting pieces of pockets with other

6) fashion parts according to the desired design

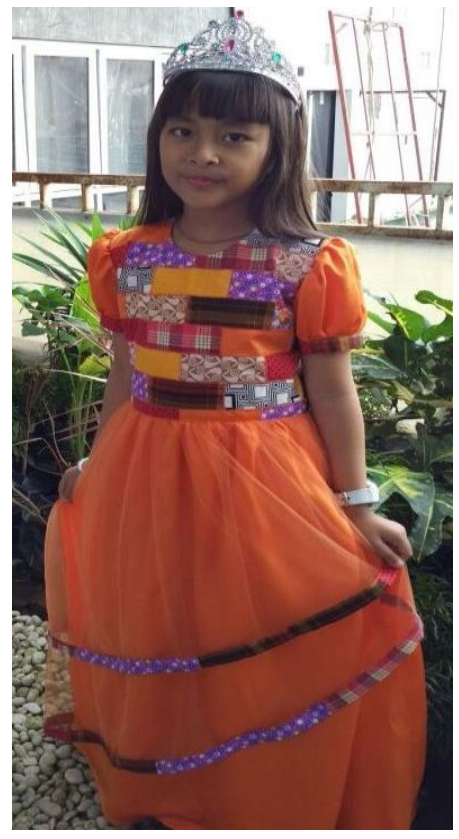

Fig. 1. Children Fashion with Fabric Waste as the Complement (source: personal documentation)
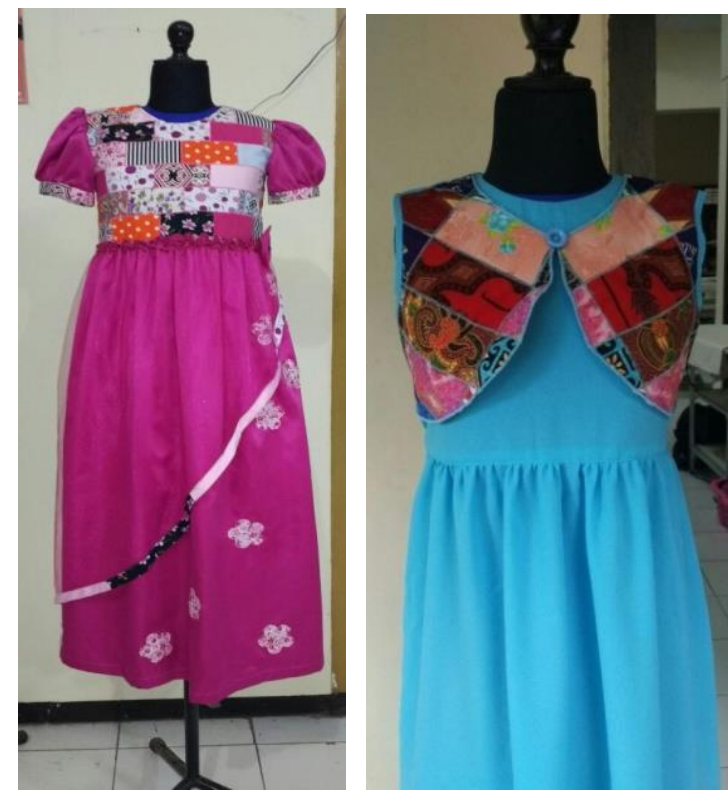

Fig. 2. Variation of Children Fashion with Fabric Waste (source: personal documentation

For small cloth scraps the fabric can be used as filler for both the cushion and the stuffed contents, while the residual cloth dyeing waste can still be reused to color the material of dried flowers, grains, and corn husks and Other dry ingredients. Of the various materials that have been colored, can be assembled and formed as a complement in the etnic wallet.

The steps in doing the staining, as follows:

1) Clean the material first to be colored 
2) Separate each one according to the material type

3) Preparing waste residue cloth dyeing

4) Enter each type of material into the liquid waste solution according to the desired color of the material

5) Perform immersion until appropriate density of the desired material

6) Drain the material, and dried in a way aerated until completely dry so as not to mold

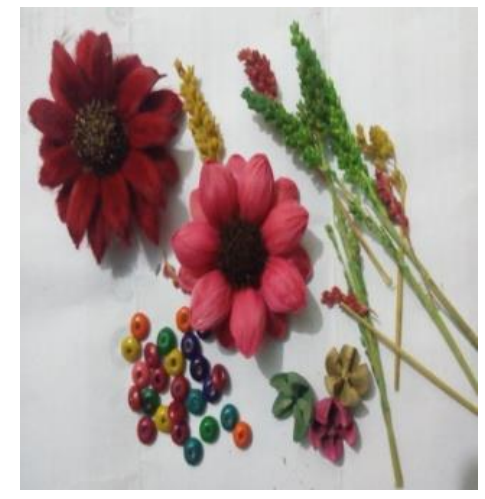

Fig. 3. Ethnic materials of Dry Flowers and Seeds Colored by Textile Dye Waste (source: personal documentation)

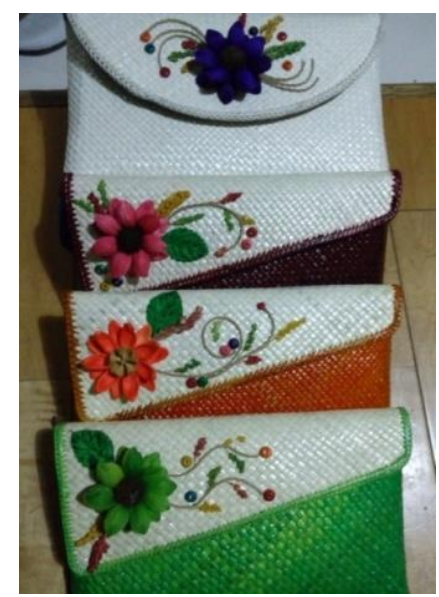

Fig. 4. Ethnic Wallets with Complement of Dry Flowers and Seeds Colored by Textile Dye Waste (source: personal documentation)

\section{CONCLUSION}

The waste treatment in the form of scraps of fabric left over from sewing practice (patchwork) and textile dye waste couldbe minimalized by recycling it. Therefore, we should encourage the students not only to produce the waste but also utilize it to produce new products.

Some solutions that can be done as a role in reducing the remaining waste of student lecture practice are:

1) Utilizing waste that is turned into a product variant, whether in the form of craft or other potential that has a sale value

2) Assign the student to create the product design from the waste generated at the end of the course.

3) Collaborate with other courses so that waste materials can be utilized as part of the materials for the product assigned

[1] Hafiuddin.2012.

\section{REFERENCES}

https://pengelolaanlimbah.wordpress.com/.../03/permasalahanlimbah-2. diakses 10 Juli 2017

[2] Rambe A.,2015. IbM Usaha Penjahit Busana Wanita dalam Pembuatan Aksesoris dari Limbah Kain Perca. JURNAL Pengabdian Kepada Masyarakat Vol. 21 Nomor 82 Tahun XXI Desember 2015

[3] Said, N. 2008. Teknologi Pengolahan Air Minum, teori dan Pengalaman Praktis. Jakarta: PTL-BPPT.

[4] Susilo, R.dan Karya, A. 2011.Pemanfaatan Limbah Kain Perca untuk Pembuatan Furniture. portalgaruda.org/article.php?article $=256228 \& \mathrm{val}=6932 \&$ title, $\quad$ diakses 15 Juli 2017.

[5] Wicaksono, K.,Rais, Z., Respati, N. Pemanfaatan Sisa Potongan kain untuk Pembuatan Ghillie Suit .http://download.portalgaruda.org/article.php?article $=256049 \&$ val $=6935 \&$ title, diakses 15 Juli 2017 . 